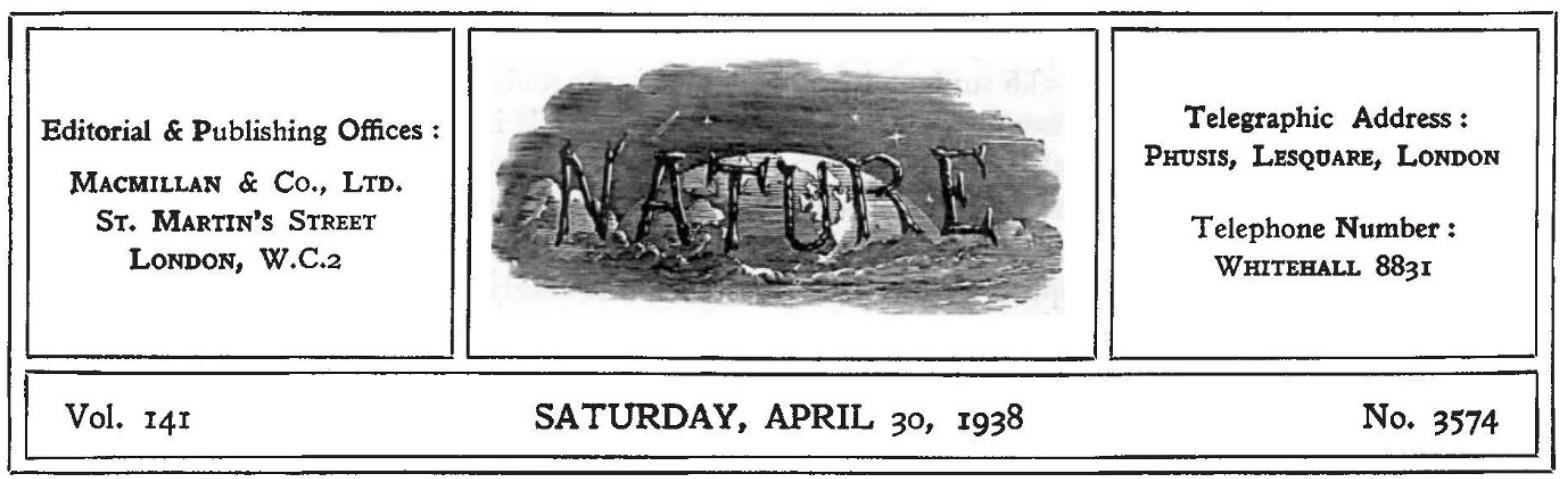

\title{
Science and Society
}

$\mathrm{A}^{\mathrm{T}}$ $\mathrm{T}$ last there are signs, in Great Britain at least, of a rapidly growing awareness of the importance of those complex problems confronting our community, due primarily to the astonishing rate of advance of scientific knowledge during the last generation, a rate which is accelerating even as we study it. Our social outlook and our social institutions toil feebly behind this advance and, lagging as they do, permit the placing of weapons of unparalleled potency for good or evil in the hands of those who may, alas, be unfit to use them. Faced with an annihilation of distance which makes it possible to put a girdle round the earth in a few days, to discuss, as an everyday matter, the possibility of establishing aeroplane factories in Canada for the supply of Britain; with methods of transport which, thanks to the labours of physicist, engineer and biologist, bring the fruits of the earth in perfect condition from the antipodes to our shores-give us, in Sir William Hardy's words, "Summer all the year round"; with the knowledge that "the growth and health of children in poor industrial areas and in the homes of many agricultural labourers are still seriously handicapped by protein and vitamin deficiencies", and that "the evidence for this has been fully substantiated by social and dietary surveys"; men of science must obviously accept a certain amount of responsibility for the solution of problems created by them.

These problems, raised by increase of knowledge, are met by social and economic - what for the use of a better word must be called 'plannings'which might have been adequate to the needs of an era when a sparsely populated nation could be considered roughly as a self-supporting economic unit ; when national patriotism, itself a plant of comparatively recent growth, was well enough fitted to the age in which it flourished; when a great man of letters could write of that bloody swathe which the dæmonic energy of Napoleon was cutting across Europe- "this war, of which philosophers take no heed"; but they are not adequate to-day, when the whole structure of civilized life is in peril. Here are problems of plenty and of deficiency, of war and of peaco, which, in the terms of their presentment, are peculiarly the products of our own age-most of them problems which the world has never before been forced to meet. What contribution can the man of science make towards their solution?

It is a moot point whether he, as a social and political animal, has been greatly influenced by his own scientific outlook. Faraday shut the door of his laboratory when he went into his oratory, and the man of science too often in the past has kept his political and scientific methods completely separate, and has been as much a victim to prejudice as his brother trained in the humanities. It is this tendency to arrive at political and ethical conclusions in terms of emotional reactions rather than rational judgments which makes government an art— the cynic would say, a dodge-rather than a science; which gives point to the demand for a "World Encyclopædia", recently stressed by Mr. H. G. Wells. It is a hopeful sign that, as was shown in the columns of the last issue of NATURE, so great a mass of considered opinion is so fully awake to the fact that it is worse than useless to meet these problems of our own age, armed with machinery devised to deal with those of the eighteenth and nineteenth centuries.

The correspondence shows a remarkable consensus of opinion. Practically all are agreed that 
some organized body is necessary which shall study the problems, many of them highly controversial, evoked by the impact of science on society, in an objective and rational manner. Such a body must have the closest linkings with the physical and biological sciences, with economics, engineering, psychology, anthropology and sociology. It must provide a platform for free and frank debate; it should conduct its investigations as much by means of research committees and discussions as by the formal reading of papers ; it should endeavour to make its findings plain to the man in the street.

There can be no question as to the need for such work to be undertaken. The present age is deafened by the cries of advertisers of nostrums of all kinds; and those of us who believe that, before all and above all, reason, and conviction by an appeal to reason, are the indispensable bases for any ordered, successful and permanent social advance, cannot but be alarmed at the growing tendency to explosions of mass-hysteria. It is only when reason provides the outlook that the emotions may be trusted to control the direction. In a society such as is proposed it is of the first importance that its explorations should be conducted and its conclusions reached in a detached and cool spirit. Coolness does not mean coldbloodedness nor does it connote any hesitation in pursuing the right path once that path is known.

The main problem being one of the interaction of science and social relations, it is clear that, as Prof. Ginsberg has put it, "the study of the effects of science on social relations requires not only a knowledge of science, but also of social relations". The problems are, in fact, sociological, and the society which undertakes the task of studying these repercussions must have a very wide field on which to draw. It may be that the ends in view will best be served by the formation of a new society charged with the special task of surveying and interpreting the social relations of science, but before actually constituting such a society, the British Association, itself a pioneer in the attack on some parts of the problem, might be invited to undertake the task.

As some correspondents have pointed out, the annual meeting of the Association provides an admirable platform from which to announce progress, but that much more than this is needed: and much more is possible. Already the Association is enlarging its activities to meet the changing needs of a changing era. It has initiated, in many of its sections, papers and discussions which touch upon these topics; it has taken part in the jubilee meeting of the Indian Science Congress Association, recently held in Calcutta, thereby establishing an important principle of overseas delegations. At the present moment its general officers are in consultation with their colleagues of the American Association for the Advancement of Science on a scheme for international co-operation such as that Association has recently adumbrated. The Association possesses sections the work of which touches closely that of a society for the study of social relations, and it is second to none in its experience of the manner of work of research committees. Is it too much to suggest that the Association might very well consider the arranging of discussions of these problems to be held in London or elsewhere at regular intervals outside the annual meeting? For the organization of such meetings, and the undertaking of appropriate investigations by research committees, an entirely new department of the Association might be constituted. It seems to us that this plan would be preferable to the addition of a new section, or sub-section, to deal with the social relations of science.

A new society of the kind contemplated implies much more than an annual report; and if the British Association accepted responsibility for its functions, either by the formation of a new department or otherwise, the present annual report would have to be supplemented by a new periodical publication comparable to the procesdings or journals of other societies, and devoted mainly to the advancement of knowledge of the impact of science on society and of society on science.

It may be that the serious questions of finance and of policy involved will make it too difficult for the Association to undertake this work. But in its constitution and outlook it is at least a possible body to undertake such duties, and its long and brilliant traditions are sufficient guarantee that the work, if undertaken, will be carried out in the true spirit of science and of public service. We suggest, therefore, that when a meeting is held to discuss proposals for constituting a body to organize inquiries into the social relations of science and publish the results, the possibility that the Association might accept this responsibility should be considered. Even if the Association fails to do so, for financial or other reasons, it might in many ways assist the work of any new society which may be formed. 